\title{
IDENTIFICATION OF FUNGI OF THE GENUS ASPERGILLUS SECTION NIGRI USING POLYPHASIC TAXONOMY
}

\author{
Daiani M. Silva ${ }^{1}$; Luís R. Batista*² ${ }^{2}$ Elisângela F. Rezende ${ }^{2}$; Maria Helena P. Fungaro ${ }^{3}$; Daniele Sartori ${ }^{3}$; Eduardo Alves $^{4}$ \\ ${ }^{1}$ Universidade Federal de Lavras, Departamento de Biologia, Lavras, MG, Brasil; ${ }^{2}$ Universidade Federal de Lavras, Departamento \\ de Ciências dos Alimentos, Lavras, MG, Brasil; ${ }^{3}$ Universidade Estadual de Londrina, Departamento de Biologia Geral, Londrina, \\ PR, Brasil; ${ }^{4}$ Universidade Federal de Lavras, Departamento de Fitopatologia, Lavras, MG, Brasil.
}

Submitted: December 22, 2009; Returned to authors for corrections: July 20, 2010; Approved: January 13, 2011.

\begin{abstract}
In spite of the taxonomy of the Aspergillus species of the Nigri Section being regarded as troublesome, a number of methods have been proposed to aid in the classification of this Section. This work aimed to distinguish Aspergillus species of the Nigri Section from foods, grains and caves on the basis in Polyphasic Taxonomy by utilizing morphologic and physiologic characters, and sequencing of ß-tubulin and calmodulin genes. The morphologic identification proved useful for some species, such as A. carbonarius and Aspergillus sp UFLA DCA 01, despite not having been totally effective in elucidating species related to $A$. niger. The isolation of the species of the Nigri Section on Creatine Sucrose Agar (CREA) enabled to distinguish the Aspergillus sp species, which was characterized by the lack of sporulation and by the production of sclerotia. Scanning Electron microscopy (SEM) allowed distinguishing the species into two distinct groups. The production of Ochratoxin A (OTA) was only found in the A. carbonarius and A. niger species. The sequencing of $\beta$-tubulin gene was efficient in differing most of the Aspergillus species from the Nigri Section with the exception of Aspergillus UFLA DCA 01, which could not be distinguished from A. costaricaensis. This species is morphologically similar to A. costaricaencis for its low sporulation capacity and high sclerotia production, but it differs morphologically from A. costaricaensis for its conidial ornamentation and size of vesicles. Equally, based on partial calmodulin gene sequence data Aspergillus UFLA DCA 01 differs from A. costaricaensis.
\end{abstract}

Key words: Polyphasic Taxonomy, $\beta$-tubulin gene, Aspergillus spp morphology.

\section{INTRODUCTION}

Species of the genus Aspergillus Section Nigri or the Black Aspergillus are widely distributed around the world and have a capacity of developing in a vast variety of substrates. Many species are able to cause deterioration of food although some of them are used in fermentation industries to produce organic acids, such as citric and gluconic acids, as well as

\footnotetext{
*Corresponding Author. Mailing address: Departamento de Ciência dos Alimentos, Universidade Federal de Lavras, UFLA, Campus da UFLA. CEP 37200000, Lavras-MG, Brazil.; Tel/Fax: + 5535 3829-1399.; E-mail: luisrb@ dca.ufla.br
} 
hydrolytic enzymes like lipases and amylases $(1,26)$. A. niger is one of the species that is widely used in biotechnological processes and it is the only one that has the "GRAS status" (Generally Regarded As Safe) by the "Food and Drug Administration". However, some species of the Section Nigri distinguish themselves by producing mycotoxins.

The taxonomy of fungi belonging to the Section Nigri comprises one of the most confusing and complex due to the subtle differences between the species. For a long time, classification and identification of these species were studied through morphologic criteria $(19,22)$. In this manner, some species, such as $A$. carbonarius and the uniseriate species ( $A$. japonicus e A. aculeatus), can be easily recognized through identification manuals; while species related to the $A$. niger aggregate complex have been difficult to distinguish using morphologic criteria Samson et al. (22). Polyphasic taxonomy has been used for identification, as well as description of new species of the genus Aspergillus (16, 18, 27). Recently, the taxonomy of the Section Nigri is undergoing reinvestigation using polyphasic taxonomy, which uses different methods (morphologic, physiologic, metabolite production and important molecular data) with the aim of simplifying and elucidating this section's confusing taxonomy.

The objective of this study was to use Polyphasic Taxonomy to identify species belonging to the Section Nigri isolated from different sources, such as foods, grains and caves.

\section{MATERIAL AND METHODS}

\section{Morphologic analysis}

One hundred and ten fungi strains belonging to the Section Nigri were used in this study. All of them were obtained from the Fungi Collection of the Mycology and Mycotoxins Laboratory of the Department of Food Sciences, Federal University of Lavras - Lavras - MG, and were isolated from different products and environments as presented in Table 1.

After pure culture, the strains were inoculated into Petri dishes containing the culture medium CYA - Czapeck Yeast Agar $\left(\mathrm{K}_{2} \mathrm{HPO}_{4} 1.0 \mathrm{~g}\right.$; Czapek concentrate $10.0 \mathrm{~mL}$; Yeast extract, $5.0 \mathrm{~g}$, Agar $15.0 \mathrm{~g}$, Distilled water 1 Liter; Czapek concentrate $\mathrm{NaNO}_{3} 30.0 \mathrm{~g}, \mathrm{KCl} 5.0 \mathrm{~g}, \mathrm{MgSO}_{4} .7 \mathrm{H}_{2} \mathrm{O}, 5.0 \mathrm{~g}$, $\mathrm{FeSO}_{4} .7 \mathrm{H}_{2} \mathrm{O} \quad 0.1 \mathrm{~g}, \mathrm{ZnSO}_{4} .7 \mathrm{H} 2 \mathrm{O} 0.1 \mathrm{~g}, \mathrm{CuSO}_{4} .5 \mathrm{H}_{2} \mathrm{O} 0.05 \mathrm{~g}$, Distilled water $100 \mathrm{~mL}$ ) and MEA (Malt Extract Agar $20.0 \mathrm{~g}$, Peptone 1.0 g, Glucose 30.0 g, Agar 20.0 g, Distilled water 1 Liter) at $25^{\circ} \mathrm{C}$ and CYA at $37^{\circ} \mathrm{C}$; in OA (Oatmeal Agar CBS $30.0 \mathrm{~g}$ of oats, $15.0 \mathrm{~g}$ of Agar, Distilled water 1 Liter) at $25^{\circ} \mathrm{C}$; CY20S (Czapeck Yeast Extract Agar with 20\% of Sucrose, $\mathrm{K}_{2} \mathrm{HPO}_{4} 1 \mathrm{~g}$, Concentrated Czapeck $10 \mathrm{~mL}$, metal solution 1 $\mathrm{mL}\left(\mathrm{ZnSO}_{4} .7 \mathrm{H}_{2} \mathrm{O} 1 \%, \mathrm{CuSO}_{4} .5 \mathrm{H}_{2} \mathrm{O} 0,5 \%\right)$, Yeast extract $5.0 \mathrm{~g}$, Sucrose $30.0 \mathrm{~g}$, Agar $15.0 \mathrm{~g}$, Distilled water 1 Liter) at $25^{\circ} \mathrm{C}$. After 7 days of incubation, the microscopic and macroscopic characteristics were observed $(14,22,23)$.

Table 1. Species of the genus Aspergillus used in this study.

\begin{tabular}{lll}
\hline Species & Origin & Species \\
\hline A.aculeatus $(0128)$ & Cave & A.niger $(01270)$ \\
A.aculeatus $(01201)$ & Raisin & A.niger $(01272)$ \\
A.aculeatus $(0113)$ & Cave & A.niger $(0191)$ \\
A.aculeatus $(01111)$ & Raisin & A.niger $(01122)$ \\
A.aculeatus $(01114)$ & Raisin & A.niger $(01129)$ \\
A.aculeatus $(01151)$ & Cave & A.niger $(01171)$ \\
A carbonarius $(01130)$ & Cave & A.niger $(01202)$ \\
A.carbonarius $(01218)$ & Raisin & A.niger $(0122)$ \\
A.carbonarius $(01244)$ & Pepper & A.niger $(0123)$ \\
A.carbonarius $(0118)$ & Raisin & A.niger $(01210)$ \\
A.carbonarius $(0121)$ & Raisin & Raisin \\
A.carbonarius $(01238)$ & Raisin & Raver $(01197)$ \\
\hline
\end{tabular}




\begin{tabular}{|c|c|c|c|}
\hline A.carbonarius (0131) & Guarana & A.niger (01278) & Cave \\
\hline A.carbonarius (0184) & Raisin & A.niger (0124) & Raisin \\
\hline A.carbonarius $(0187)$ & Raisin & A.niger $(0175)$ & Raisin \\
\hline Aspergillus sp DCA UFLA (01162) & Cave & A.niger (01209) & Cashew nut \\
\hline A.foetidus (01236) & Guarana & A.niger (0115) & Raisin \\
\hline A.foetidus (01132) & Raisin & A.niger (0105) & Raisin \\
\hline A.foetidus (01133) & Raisin & A.niger (0166) & Raisin \\
\hline A.foetidus (01134) & Raisin & A.niger (0116) & Raisin \\
\hline A.foetidus (01135) & Raisin & A.niger (0117) & Raisin \\
\hline A.foetidus (01158) & Raisin & A.niger (0183) & Raisin \\
\hline A.foetidus (0143) & Raisin & A.niger (01115) & Raisin \\
\hline A.foetidus (01119) & Raisin & A.niger $(01121)$ & Raisin \\
\hline A.foetidus (01124) & Raisin & A. niger (01345) & Raisin \\
\hline A.foetidus (01125) & Raisin & A.niger (01224) & Guarana \\
\hline A.foetidus (0168) & Raisin & A.niger (01343) & Raisin \\
\hline A.foetidus (01254) & Bean & A.niger (81) & Coffee \\
\hline A.foetidus (01204) & Cave & A.niger (84) & Coffee \\
\hline A.foetidus $(01340)$ & Hazelnut & A.niger (78) & Coffee \\
\hline A.foetidus (01123) & Raisin & A.niger (75) & Raisin \\
\hline A.foetidus (01159) & Cave & A.niger (72) & Raisin \\
\hline A.foetidus (01213) & Cashew nut & A.niger $(01208)$ & Almond \\
\hline A.foetidus (01296) & Cashew nut & A.niger Aggregate (0176) & Coffee \\
\hline A.foetidus (01205) & Cave & A.niger Aggregate (01235) & Guarana \\
\hline A.foetidus (01140) & Raisin & A.niger Aggregate (01239) & Raisin \\
\hline A.foetidus (01206) & Cave & A.niger Aggregate (01172) & Raisin \\
\hline A.foetidus (01168) & Raisin & A.niger Aggregate (01147) & Guarana \\
\hline A.foetidus (01380) & Guarana & A.niger Aggregate (0119) & Raisin \\
\hline A.foetidus (01284) & Cashew nut & A.niger Aggregate (01137) & Raisin \\
\hline A.foetidus (01286) & Coffee & A.niger Aggregate (01175) & Raisin \\
\hline A.foetidus (01242) & Guarana & A.niger Aggregate (01289) & Cocoa \\
\hline A.foetidus (01269) & Hazelnut & A.niger Aggregate (01257) & Bean \\
\hline A.foetidus (01282) & Cocoa & A.niger Aggregate (01336) & Hazelnut \\
\hline A.japonicus (01184) & Cave & A.niger Aggregate (0192) & Raisin \\
\hline A.japonicus (01148) & Cave & A.niger Aggregate (01215) & Pistachio nut \\
\hline A.japonicus (0125) & Cave & A.niger Aggregate (01191) & Cave \\
\hline A.japonicus (01182) & Cave & A.tubingensis (01248) & Pepper \\
\hline A.japonicus (01161) & Cave & A.tubingensis (01196) & Raisin \\
\hline A.niger $(01278)$ & Almond & A.tubingensis (01176) & Raisin \\
\hline A niger (01207) & Cave & A.tubingensis (01200) & Raisin \\
\hline A niger (01216) & Raisin & A.tubingensis (0102) & Raisin \\
\hline A.niger $(0165)$ & Raisin & A.tubingensis (01144) & Raisin \\
\hline A niger (01292) & Cashew nut & A.tubingensis(01260) & Raisin \\
\hline A niger (01217) & Rice & A.tubingensis (01233) & Raisin \\
\hline
\end{tabular}

\section{Growth and acid production in CREA (Creatine Sucrose}

\section{Agar) culture medium}

The capabilities of growth and production of acid by the cultures were tested in CREA medium (Creatine Sucrose Agar - Creatine $3.0 \mathrm{~g}$, Sucrose $30 \mathrm{~g}, \mathrm{KCl} 0.5 \mathrm{~g}, \mathrm{MgSO}_{4} .7 \mathrm{H}_{2} \mathrm{O} 0.5 \mathrm{~g}$, $\mathrm{FeSO}_{4} .7 \mathrm{H}_{2} \mathrm{O} 0.5 \mathrm{~g}, \mathrm{~K}_{2} \mathrm{HPO}_{4} .3 \mathrm{H}_{2} \mathrm{O} 1.3 \mathrm{~g}$, Bromocresol purple $0.05 \mathrm{~g}$, Agar $15.0 \mathrm{~g}$, Distilled water 1 Liter) according to Frisvad and Samson (7, 22).

Determining the ochratoxigenic potential of the identified

\section{species}

In order to determine the toxigenic potential of the species, the Plug Agar methodology, described by Filtenborg \& Frisvad (6), was used.

\section{Extraction of Genomic DNA}

Conidia of the Aspergillus strains were inoculated in a complete liquid medium $\left(\mathrm{NaNO}_{3} 6.0 \mathrm{~g} ; \mathrm{KH}_{2} \mathrm{PO}_{4} 1.5 \mathrm{~g}\right.$; $\mathrm{MgSO}_{4} .7 \mathrm{H}_{2} \mathrm{O} 0.5 \mathrm{~g} ; \mathrm{KCl} 0.5 \mathrm{~g} ; \mathrm{FeSO}_{4} 0.001 \mathrm{~g} ; \mathrm{ZnSO}_{4} 0.001 \mathrm{~g}$; glucose $10.0 \mathrm{~g}$; Yeast extract $0.5 \mathrm{~g}$; Peptone $2.0 \mathrm{~g}$; Hydrolyzed 
casein $1.5 \mathrm{~g}$; Vitamin solution $1 \mathrm{~mL}$; Distilled water $1 \mathrm{~L}$ ) and incubated at $28^{\circ} \mathrm{C}$, for 24 hours, at $180 \mathrm{rpm}$ (20). The genomic DNA was extracted according to Azevedo (4) and measured using the fluorimetric method (Dyna Quant, Pharmacia).

\section{DNA amplification and sequencing}

Primers used to amplify a region of the $\beta$-tubulin and calmodulin genes were obtained from Glass and Donaldson (9) and Hong et al (10), respectively. The $50 \mu \mathrm{L}$ PCR reaction mixtures contained $20 \mathrm{ng}$ of genomic DNA, $10 \mathrm{mM}$ Tris- $\mathrm{HCl}$ ( $\mathrm{pH} \mathrm{8.3),} 50 \mathrm{mM} \mathrm{KCl}, 2.0 \mathrm{mM} \mathrm{MgCl}_{2}, 0.2 \mathrm{mM}$ of dNTP, 0.4 $\mu \mathrm{M}$ of each primer and $2.0 \mathrm{U}$ of Taq DNA polymerase (Invitrogen). The mixtures was subjected to the following amplification program: initial denaturation at $94^{\circ} \mathrm{C}$ for $5 \mathrm{~min}$, followed by 35 cycles of denaturation $\left(94^{\circ} \mathrm{C}, 1 \mathrm{~min}\right)$, primer annealing $\left(64^{\circ} \mathrm{C}, 30 \mathrm{~s}\right)$ and elongation $\left(72^{\circ} \mathrm{C}, 1 \mathrm{~min}\right)$, and a final elongation for $5 \mathrm{~min}$ at $72^{\circ} \mathrm{C}$. DNA fragments were purified with the CONCERT $^{\mathrm{TM}}$ Rapid PCR Purification System (GIBCOBRL, UK). The sequencing reaction was performed by using DYEnamic ${ }^{\mathrm{TM}}$ ET dye Terminator Cycle Sequencing Kit (Amersham Pharmacia Biotech, Inc.) on MegaBACE 1000 (Amersham Biosciences).

\section{Sequence analysis}

The quality of the sequences was analyzed using the Phre/Phrap/Consel package. For identification of the strains, the obtained nucleotide sequences were compared to those already stored in the National Center for Biotechnology and Information (NCBI) sequence database, using a research tool, BLAST (3).

\section{Sample preparation for analysis using a Scanning Electron Microscope}

Seven significant strains of each species belonging to the Section Nigri (Table 1) and initially identified using traditional methods analyzed in this work were inoculated in CYA $25{ }^{\circ} \mathrm{C}$ for 5 days. After the incubation period, the sample discs were immersed in a fixative solution (Modified Karnovsky`s fixative $2.5 \%$ glutaraldehyde $-2.5 \%$ paraformaldehyde, $0.05 \mathrm{M}$ cacodilate buffer, $\mathrm{CaCl}_{2} 0.001 \mathrm{M}$ ) at $\mathrm{pH}$ 7.2. The discs were then washed in cacodilate buffer (three times, for $10 \mathrm{~min}$ each wash), post-fixed in $1 \%$ osmium tetroxide solution and water for 1 hour and washed three times in distilled water, followed by dehydration in increasingly more concentrated acetone solutions $(25,50,75,90$ and $100 \%$, once for concentrations up to $90 \%$ and thrice for the $100 \%$ concentration). Afterwards, the samples were transferred to a desiccator containing silica to complete the drying process. The specimens obtained were assembled in aluminum supports known as stubs, with a double-faced carbon tapes put on a film of aluminum foil, covered with gold in a sputter (BALZERS SCD 050) and observed in a scanning electron microscope LEO EVO 40XVP. A number of images for each sample were digitally produced and registered at variable magnifications.

\section{RESULTS AND DISCUSSION}

\section{Morphology of the colonies}

The strains belonging to the genus Aspergillus Section Nigri characteristically present dark-brown to black conidia, with uniseriate or biseriate conidiophores, spherical vesicles and hyaline or lightly pigmented hyphae near the apex (12).

Figure 1 presents the growth characteristics of the species Aspergillus Section Nigri studied in CYA and MEA $25^{\circ} \mathrm{C}$ after 7 days in culture. Aspergillus sp UFLA DCA 01 could be distinguished due to its low capacity of sporulation and its abundant production of oval shaped sclerotia with a yelloworange color with gray tones. This strain is morphologically similar to the species A. costaricaensis. However, Aspergillus sp DCA 01 can be macroscopically distinguished from $A$. costaricaensis by the color of the mycelium. Aspergillus $\mathrm{sp}$ has a white mycelium, while A. costaricaensis has a yellow mycelium. Other differences between these two species are: the reverse color in MEA $25^{\circ} \mathrm{C}$ (Table 2) and the sclerotia colors, 
that of A. costaricaensis varies from pink to yellow with gray tones, while that of Aspergillus UFLA DCA 01 is light brown.

The species A. tubingensis is morphologically very similar to A. niger, what makes it difficult to distinguish them based only on morphological information. Nevertheless, in this study A. tubingensis could be macroscopically distinguished by its production of sclerotia, which present a characteristic white to pink color. Although Samson et al. (22) reported that the sclerotia production by species of $A$. tubingensis is not always observed. Studies demonstrated that the other species have a capacity to produce these structures, including A. carbonarius,
A. ellipticus, A. aculeatus, A. costaricaensis, A. piperis, A. sclerotioniger, A. aculeatinus and A. sclerotiicarbonarius (22, 23). However, these structures were never observed in the species of A. ibericus (24).

The results also describe a morphologic similarity between Aspergillus niger Aggregate and A. niger, A. tubingiensis and A. foetidus. Morphologically, the differences are subtle as already observed by other authors (22). In relation to the uniseriate species, including $A$. japonicus and $A$. aculeatus, these could not be distinguished based only on the macroscopic observation of their morphological characteristics.
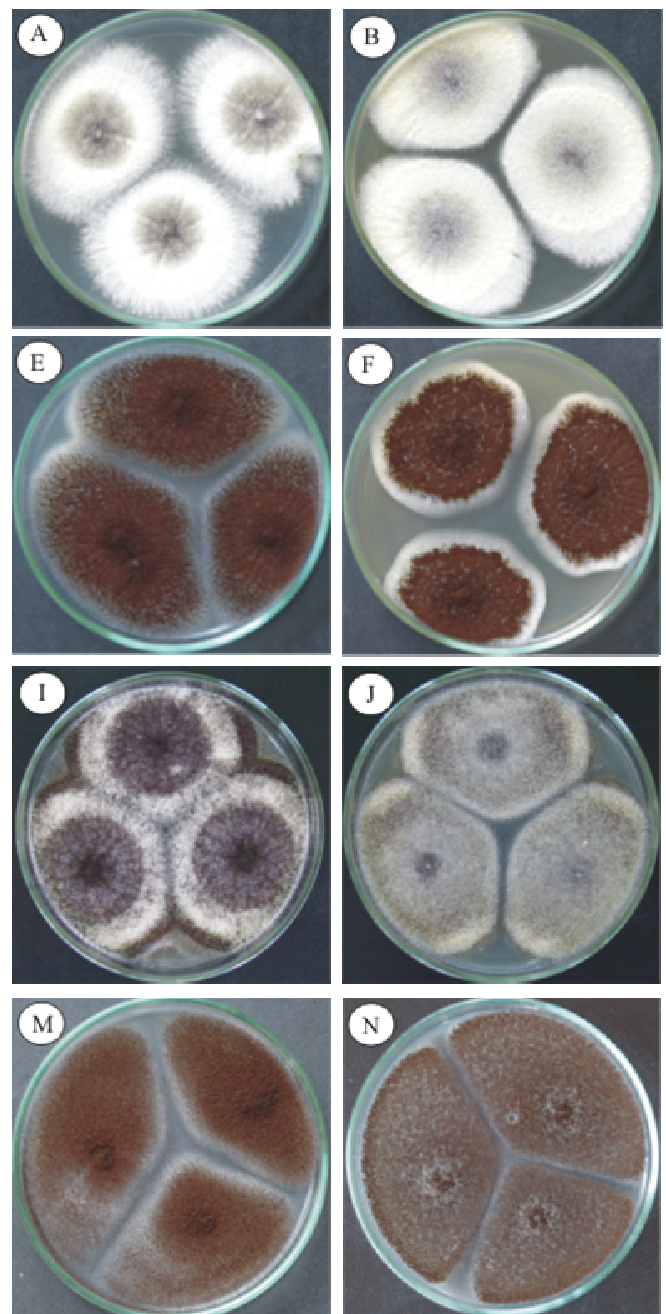
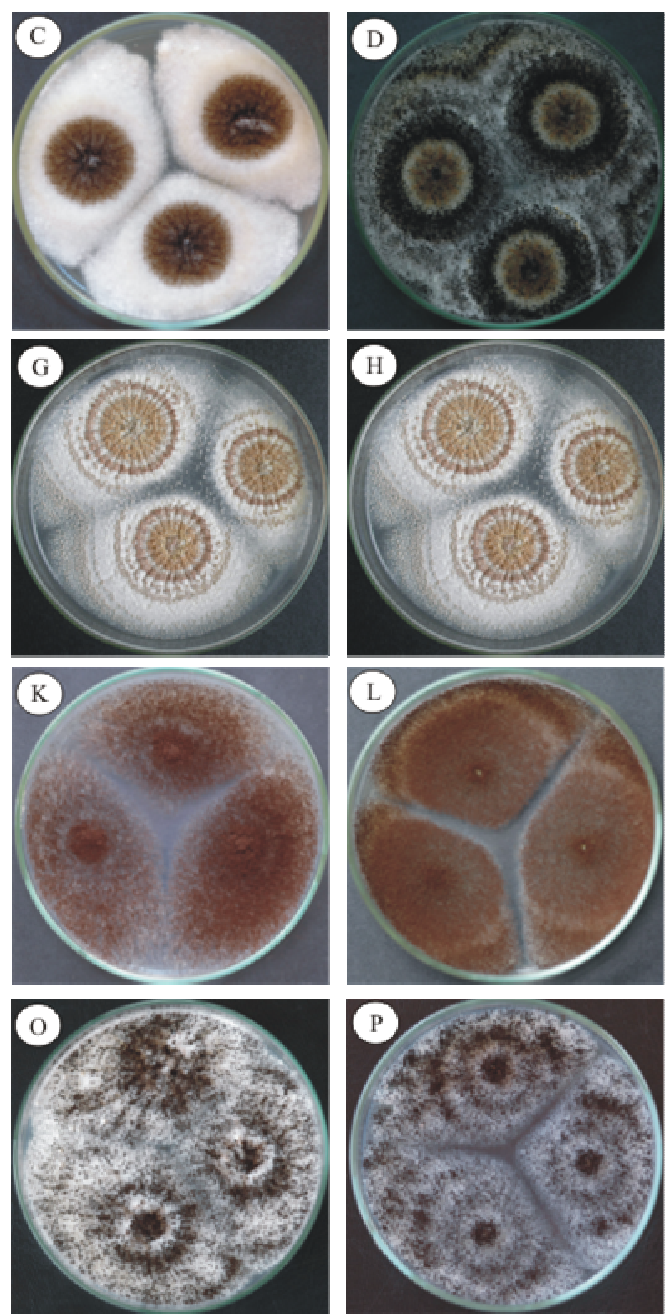

Figure 1. Photographs of the colonies of Aspergillus Section Nigri in CYA and MEA $25{ }^{\circ} \mathrm{C}$ after 7 days showed morphologic differences. A. aculeatus (A-B); A. carbonarius (C-D); A. foetidus (E-F); Aspergillus sp UFLA DCA 01 (G-H); A. japonicus (I-J); A. niger (K-L); A. niger Aggregate (M-N); A. tubingensis (O-P). 
Table 2. Macroscopic characteristics of the species of Aspergillus Section Nigri

\begin{tabular}{|c|c|c|c|c|c|c|c|c|}
\hline \multirow[b]{2}{*}{ Species } & \multicolumn{3}{|c|}{ Colony CYA $25^{\circ} \mathrm{C}$} & \multicolumn{3}{|c|}{ Colony MEA $25^{\circ} \mathrm{C}$} & \multirow[b]{2}{*}{$\begin{array}{l}\text { Production } \\
\text { of sclerotia }\end{array}$} & \multirow[b]{2}{*}{$\begin{array}{l}\text { Production } \\
\text { of OTA }\end{array}$} \\
\hline & $\begin{array}{c}\text { Diameter of } \\
\text { colony }\end{array}$ & Color & Reverse color & $\begin{array}{c}\text { Diameter of } \\
\text { colony }\end{array}$ & Color & $\begin{array}{c}\text { Reverse } \\
\text { color }\end{array}$ & & \\
\hline A. aculeatus & $73-76$ & $\begin{array}{l}\text { Dark brown/ } \\
\text { gray tones }\end{array}$ & Pale to yellow & $74-79$ & $\begin{array}{l}\text { Dark brown/ } \\
\text { gray tones }\end{array}$ & $\begin{array}{l}\text { Straw- } \\
\text { colored }\end{array}$ & Absent & - \\
\hline A. carbonarius & $65-67$ & Black & Colorless & $51-57$ & Black & Colorless & Absent & + \\
\hline A. foetidus & $62-65$ & $\begin{array}{l}\text { Dark brown } \\
\text { to black }\end{array}$ & $\begin{array}{l}\text { Tones of gray to } \\
\text { brown center }\end{array}$ & $62-66$ & Black & Colorless & Absent & - \\
\hline A. japonicus & $67-73$ & $\begin{array}{l}\text { Dark brown/ } \\
\text { gray tones }\end{array}$ & Pale to yellow & $64-70$ & $\begin{array}{l}\text { Dark brown/ } \\
\text { to black }\end{array}$ & Colorless & Absent & - \\
\hline A. niger & $67-70$ & $\begin{array}{l}\text { Black to dark } \\
\text { brown }\end{array}$ & $\begin{array}{l}\text { Colorless to } \\
\text { light yellow }\end{array}$ & $53-69$ & Black & Colorless & Absent & + \\
\hline A. niger Aggregate & $65-69$ & $\begin{array}{l}\text { Dark brown/ } \\
\text { to black }\end{array}$ & Straw-colored & $64-68$ & $\begin{array}{l}\text { Dark brown/ } \\
\text { to black }\end{array}$ & $\begin{array}{l}\text { Light } \\
\text { yellow }\end{array}$ & Absent & - \\
\hline A. tubingensis & $65-72$ & Black & Pale & $56-57$ & Black & Colorless & Present & - \\
\hline $\begin{array}{l}\text { Aspergillus sp } \\
\text { UFLA DCA } 01\end{array}$ & $75-76$ & Black & Cream & $65-71$ & Black & Colorless & $\begin{array}{c}\text { Present } \\
\text { (abundant) }\end{array}$ & - \\
\hline *A. costaricaensis & $63-78$ & Black & Straw-colored & $26-62$ & Black & Yellow & $\begin{array}{c}\text { Present } \\
\text { (abundant) }\end{array}$ & - \\
\hline
\end{tabular}

*A. costaricaensis - listed in the table for comparison of the characteristics of Aspergillus sp UFLA DCA 01.

\section{Conidial ornamentation}

Among the biseriate species, A. carbonarius could be easily distinguished from the other species based on size and conidial ornamentation, whose diameter varied from 7 to $9 \mu \mathrm{m}$, although some reached $10 \mu \mathrm{m}$. Other species that produce large conidia include A. homomorphus, A. sclerotiicarbonarius, A. sclerotioniger $(22,23)$ and A. ibericus $(22,23,24)$. The rest of the species studied presented conidia with varying sizes, between 3 to $5 \mu \mathrm{m}$. Aspergillus foetidus, A. niger and A. tubingensis are species that are difficult to distinguish based on morphology (22); however, A. foetidus could be distinguished from these species by its conidial ornamentation, which when formed present themselves as delicately spiny and, when mature, as smooth conidia. The uniseriate species A. aculeatus and A. japonicus could not be distinguished by their conidial ornamentation as both present spiny conidia. Although these two species are morphologically similar, some differences were observed. A. aculeatus presents larger vesicles compared to those of A. japonicus. Another characteristic that was observed and which helped distinguish these two species was the shape of the conidia; the species A. aculeatus presents predominantly ellipsoidal conidia while A. japonicus, presents globular and subglobular conidia (Figure 2), as was noted by Klich (12).

Aspergillus sp UFLA DCA 01 presented conidia with a spiny ornamentation to a finely wrinkled one, what differs from the ornamentation presented by $A$. costaricaensis, smooth conidia to distinctly wrinkled (Table 3 ).

The spore ornamentation as observed in MEV permitted the distinction of two groups of the analyzed species of Aspergillus Section Nigri: those that presented warty conidia and those that presented echinulated conidia (Figure 2). The species that present warty conidia are: A. niger, A. niger aggregate, A.carbonarius and A. tubingensis. The spores of $A$. japonicus and A. aculeatus are distinctly echinulated. 

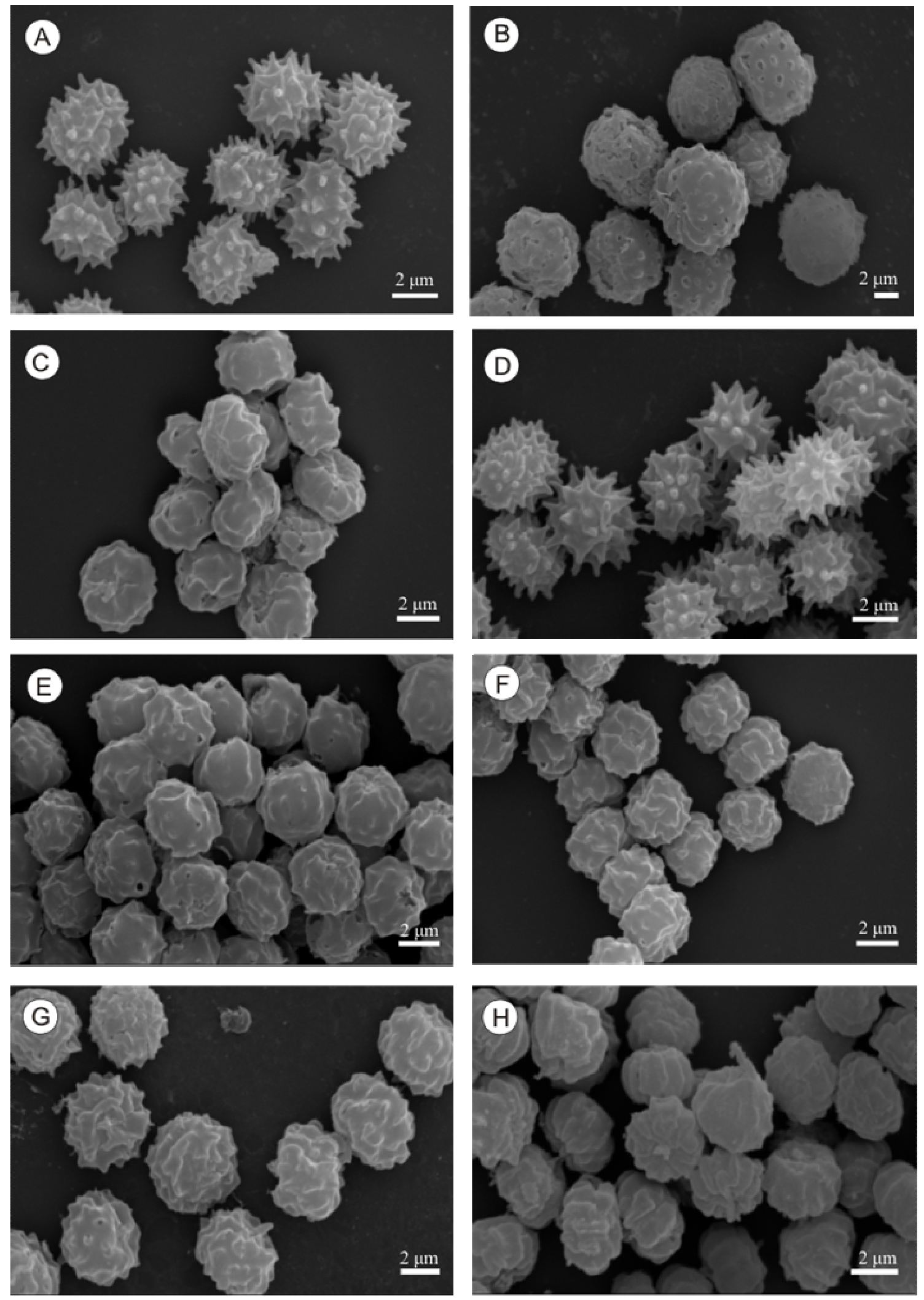

Figure 2. Scanning electron micrographs of the conidia of Aspergillus Section Nigri. A.aculeatus (A); A. carbonarius (B); A.foetidus (C); A. japonicus (D); A.niger Aggregate (E); A niger (F), A. tubingensis (G), Aspergillus sp UFLA DCA 01 (H). 
Table 3. Microscopic characteristics of the species of Aspergillus Section Nigri

\begin{tabular}{|c|c|c|c|c|c|}
\hline Species & $\begin{array}{c}\text { Diameter of } \\
\text { Conidia }(\mu \mathrm{m})\end{array}$ & Texture of Conidia & Shape of Conidia & $\begin{array}{c}\text { Diameter of } \\
\text { Vesicles (mm) }\end{array}$ & $\begin{array}{c}\text { Conidial } \\
\text { Ornamentation } \\
(\mathrm{MEV})\end{array}$ \\
\hline \multicolumn{6}{|l|}{ Uniseriate } \\
\hline A. aculeatus & $4-5$ & spiny & Ellipsoidal & $31-60$ & echinulated \\
\hline A. japonicus & $4-5$ & spiny & subglobular/globular & $16-33$ & echinulated \\
\hline \multicolumn{6}{|l|}{ Biseriate } \\
\hline A. carbonarius & $7-10$ & Wrinkled & Globular & $49-85$ & warty \\
\hline A. foetidus & $4-5$ & delicately spiny/smooth & Globular & $34-69$ & - \\
\hline A. niger & $3-5$ & finely wrinkled/wrinkled & globular/ ellipsoidal & $20-73$ & warty \\
\hline A. niger Aggregate & $4-5$ & smooth/finely wrinkled & Globular & $18-54$ & warty \\
\hline A. tubingensis & $4-5$ & finely wrinkled/wrinkled & globular/ subglobular & $45-69$ & echinulated / warty \\
\hline $\begin{array}{l}\text { Aspergillus } \\
\text { DCA } 01\end{array}$ & $4-5$ & spiny/ finely wrinkled & globular/ subglobular & $10-14$ & - \\
\hline A. costaricaensis & $3.1-4.5$ & smooth/distinctly wrinkled & globular/subglobular & $45-90$ & echinulated \\
\hline
\end{tabular}

*A. costaricaensis - listed in the table for comparison of the characteristics of Aspergillus sp UFLA DCA 01

\section{Growth and acid production in CREA (Creatine Sucrose}

\section{Agar) culture medium}

This selective medium is widely used for the classification of a number of fungal cultures, especially in species of the genus Penicillium $(7,22)$. Recently, this medium was used to divide the species of Aspergillus Section Nigri into groups according to their acid production (23). All the tested species presented a capacity to grow in CREA, forming a yellow halo around the colonies. The biseriate species A. carbonarius and A. niger aggregate presented the greatest capacity of growth in this medium compared to the other tested species, as well as good acid production. Aspergillus foetidus, A. niger, A. tubingensis and Aspergillus sp UFLA DCA 01 presented moderate growth and good acid production. According to Samson et al. (23), some species like A. sclerotiicarbonarius manifest incapacity to grow in CREA, one of the characteristics that allow the distinction of this species from $A$. carbonarius, A. sclerotioniger and A. ibericus, which belong to the Section Nigri.

In relation to $A$. aculeatus and A. japonicus, these uniseriate species also present moderate growth and limited acid production compared to the biseriate species. Samson et al. (23) also observed limited acid production by the uniseriate species A. aculeatus, A. japonicus and A. uvarum in CREA.

\section{Evaluation of the ochratoxigenic potential}

Two species of the strains listed in Table 1 presented themselves to be potentially capable of producing OTA. Out of 39 A. niger strains, 6 species were capable of producing OTA. Some studies confirmed $A$. niger to be an OTA producer although the OTA production by these species is rarely reported $(5,11,25)$. In relation to the species of $A$. carbonarius, 6 out of 9 tested species were potentially capable of producing OTA. This specie is considered to be a major OTA producer in grapes and grape derivatives (21).

The rest of the species listed in Table 1 did not produce 
OTA. However, other studies reported OTA production by species of $A$. foetidus (15) and, recently, the species of $A$. tubingensis and $A$. japonicus were reported to be species capable of producing OTA (17). To Samson et al. (22), the species of A. tubingensis were never capable of producing OTA. The same authors also reported OTA production by the species of A. carbonarius, A. sclerotioniger, A. niger and A. lacticoffeatus, belonging to the Section Nigri.

\section{Molecular characterization to distinguish species of Aspergillus Section Nigri}

The cladogram indicates the presence of two clades of the phylogenetic tree based on sequencing of the B-tubulin gene. The smaller clade comprises the uniseriate species $A$. japonicus and A. aculeatus, while the larger clade comprises species of the A. niger complex and is subdivided into subclades (Figure 3). Subclade I is represented by the uniseriate species A. homomorphus, A. aculeatinus and A. uvarum.

Subclade II is represented by the species $A$. heteromorphus and subclade III by the species A. ellipticus.

Morphologically identified isolates like A. carbonarius 01218 and 01238 are grouped together with the species $A$. carbonarius CBS 11126 present in subclade IV. The species $A$. ibericus, A. sclerotiicarbonarius and A. sclerotioniger, also present in subclade IV, form a distinct group because they share some characteristics, such as OTA production, sclerotia production and larger conidia, when compared to the rest of the species that belong to the Section Nigri $(22,23)$.

Subclade V comprises a larger group, including the species A. brasiliensis, A. vadensis, A. tubingensis, A. costaricaensis, A. piperis and A. foetidus, A. niger and A. lacticoffeatus, related to the A. niger complex (2). This subclade also includes Aspergillus sp UFLA DCA 01 (01162), which is grouped together with the species of A. costaricaensis. These two species could be morphologically distinguished by growth and reverse pigmentation in MEA $25^{\circ} \mathrm{C}$, as well as the color of their sclerotia. The conidial morphology is also different since Aspergillus sp UFLA DCA 01 presents spiny to finely wrinkled conidia while $A$. costaricaensis presents smooth to distinctly wrinkled conidia. The vesicle size in $A$. costaricaensis (40-90) is larger than that of Aspergillus $\mathrm{sp}$ UFLA DCA 01. The B-tubulin gene was not efficient in the distinction of these two species. As had already been noted by Samson et al. (22), in Aspergillus Section Nigri all species can be distinguished from each other using calmodulin sequence data, with is not true by using $\beta$-tubulin sequence data. Based on this observation, we amplified and sequenced a portion of calmodulin gene by using DNA from the Aspergillus sp UFLA DCA 01. The alignment of 445 nucleotide positions from Aspergillus sp UFLA DCA 01 with those from $A$. costaricaensis strains revealed eight $(1.8 \%)$ single nucleotide polymorphisms (Figure 4). This level of variation is high enough to suggest that Aspergillus sp UFLA DCA 01 is in fact a new species of Section Nigri.

Fungi morphologically identified as A. tubingensis (01176, 01233, 01248, 01260), also present in the subclade V were grouped together with the species A. tubingensis. A. tubingensis is a species which is morphologically very similar to A. niger. However, A. tubingensis could be distinguished by production of white to pink colored sclerotia, a characteristic of this species; this structure is rarely observed in the species of $A$. niger (22). Despite the difficulty to differentiate between $A$. tubingensis and A. niger using phenotypic methods, these species can be distinguished through sequencing of the $\beta$ tubulin gene (26).

Based on morphologic characters, the fungi (01224, $01343,78,81,84$ e 01345$)$ were classified as $A$. niger. The phylogenetic analysis revealed that these were strains to $A$. lacticoffeatus, thus they were characterized as A. lacticoffeatus.

A. lacticoffeatus is a species that is morphologically very similar to A. niger. According to Samson et al. (22), based on the B-tubulin gene sequences (Bt2a and $\mathrm{Bt} 2 \mathrm{~b}$ ), these two species cannot be separated since they present identical gene 
sequences $(22,25)$, although, Geiser et al. (8) had reported that these two species could be distinguished using the ß-tubulin gene. To Samson et al. (22), A. lacticoffeatus can morphologically be distinguished from A. niger through the ornamentation and color of the conidia, by pigmentation in medium culture and by secondary metabolite profile (extrolytes). In this study, strains with characteristics similar to that of A. lacticoffeatus were grouped in this clade.

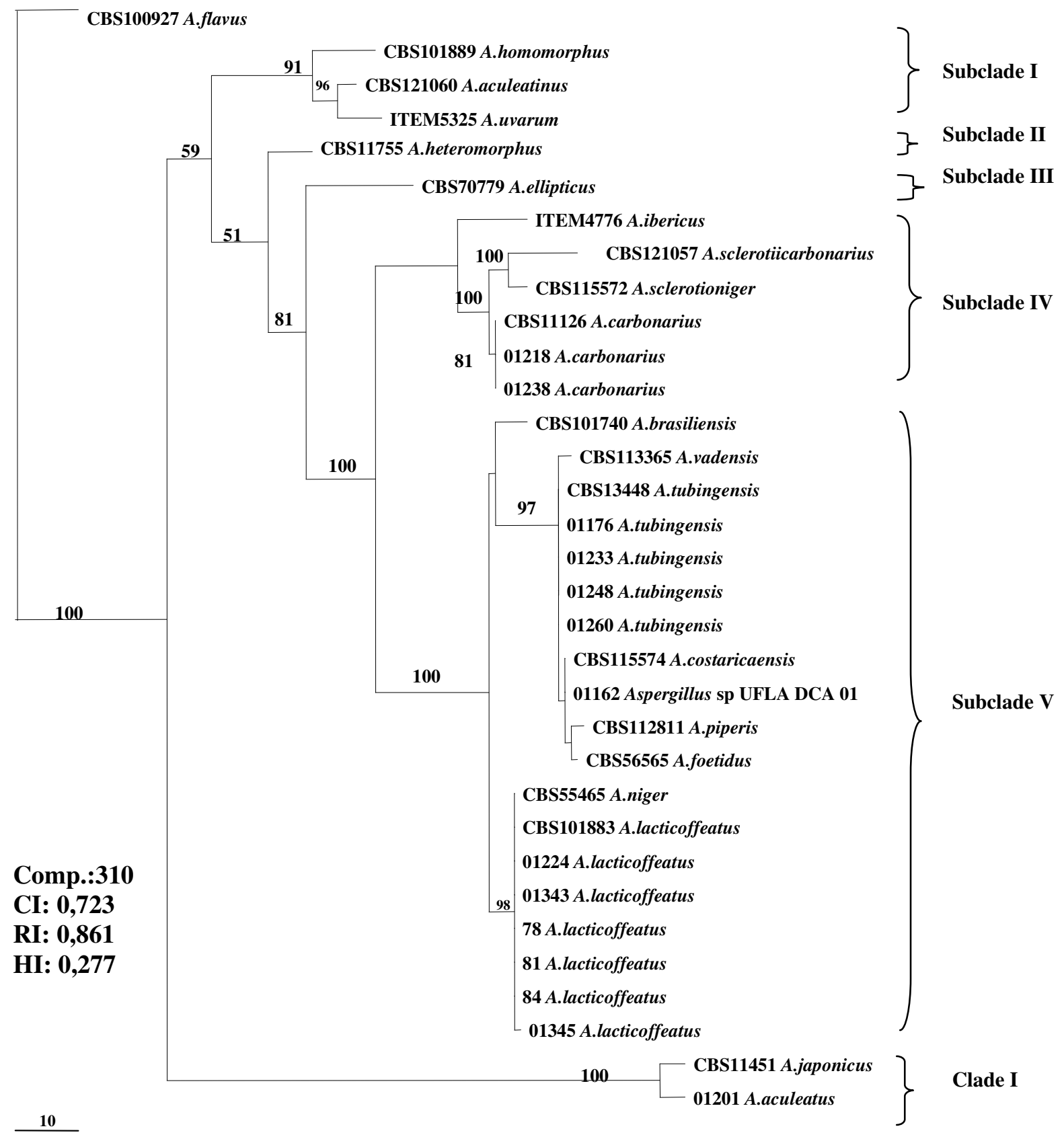

Figure 3. Maximum Parsimony Phylogenetic Tree based on the $\beta$-tubulin gene of species belonging to the Section Nigri. The length of the branches is indicated by scale at the tree base and the bootstrap values (1000 repetitions) are shown as a percentage at the internodes. 
Clade I is represented by uniseriate species. The strain morphologically identified as A. aculeatus 01201 was grouped in the same clade as A. japonicus, with $100 \%$ difference between these species. Although these two species are morphologically similar, some differences, such as conidial and vesicle morphology permit distinction (12).

The clades generated in the chromatogram reveal formation of groups with related morphologic and physiologic characteristics, permitting the manual identification of some species. The usage of $B-$ tubulin gene sequencing allows comparison with other species in the GenBank, although Aspergillus sp UFLA DCA 01 presents remarkable morphologic characteristics and can be characterized as a new species, despite the fact that it belongs to the same clade as $A$. costaricaensis. The morphologic differences can be an important tool for characterization of a new species even in members of the same clade. Thus, Polyphasic Taxonomy not only generates large amounts of information about the strain, but also permitted description, from fungal groups and of a new species of the genus Aspergillus Section Nigri.

From the results obtained in this study, it can be concluded that Polyphasic Taxonomy proved to be the most precise method for identification of species of Aspergillus Section Nigri.

\begin{tabular}{|c|c|c|c|c|c|c|}
\hline \multirow{2}{*}{55} & \multirow{2}{*}{5} & \multirow{2}{*}{15} & \multirow{2}{*}{25} & \multirow{2}{*}{\multicolumn{2}{|c|}{35}} & \multirow{2}{*}{45} \\
\hline & & & & & & \\
\hline EU163268.1 & TCAATAGGAC & AAGGATGGCG & ATGGTGGGTG & GAATTCTGTC & CCCTTCACGT & TTTACCTGTA \\
\hline FN594545.1 & TCAATAGGAC & AAGGATGGCG & ATGGTGGGTG & GAATTCTGTC & СССТTCACGT & TTTACCTGTA \\
\hline UFLADCA0 1 & TCAATAGGAC & AAGGATGGCG & ATGGTGGGTG & GAATTCTGTC & CCCTTCACGT & TTTACCTGTA \\
\hline & 65 & 75 & 85 & 95 & 105 & 115 \\
\hline EU163268.1 & GCGCTCGATC & CGACCGCGGG & ATTTCGACAG & ССАТТССССС & ATCGATCTCA & ATCATTATAC \\
\hline FN594545.1 & GCGCTCGATC & CGACCGCGGG & ATTTCGACAG & ССАТТССССС & ATCGATCTCA & ATCATTATAC \\
\hline \multirow[t]{2}{*}{ UFLADCA01 } & GCGCTCCATC & CGACCGCGGG & ATTTCGACAG & CCATTCCCCC & ATCGATCTTA & ATAATTATAC \\
\hline & 125 & 135 & 145 & 155 & 165 & 175 \\
\hline EU163268.1 & TGATGTAATC & CGGAAATAGG & CCAGATCACC & ACCAAGGAGC & TCGGCACTGT & GATGCGCTCC \\
\hline FN594545.1 & TGATGTAATC & CGGAAATAGG & CCAGATCACC & ACCAAGGAGC & TCGGCACTGT & GATGCGCTCC \\
\hline \multirow[t]{2}{*}{ UFLADCA01 } & TGATGTAATC & TGGAAATAGG & CCAGATCACC & ACCAAGGAGC & TCGGCACTGT & GATGCGCTCC \\
\hline & 185 & 195 & 205 & 215 & 225 & 235 \\
\hline EU163268.1 & CTCGGCCAGA & ACCCCTCCGA & GTCTGAGCTT & CAGGACATGA & TCAACGAGGT & TGACGCTGAC \\
\hline FN594545.1 & CTCGGCCAGA & ACCCCTCCGA & GTCTGAGCTT & CAGGACATGA & TCAACGAGGT & TGACGCTGAC \\
\hline \multirow[t]{2}{*}{ UFLADCA01 } & CTCGGCCAGA & ACCCCTCCGA & GTCTGAGCTT & CAGGACATGA & TCAACGAGGT & TGACGCTGAC \\
\hline & 245 & 255 & 265 & 275 & 285 & 295 \\
\hline EU163268.1 & AACAACGGAA & CGATCGACTT & CCCCGGTATG & TGATAGATCT & ACGCCTGTAA & GGCGGGAATG \\
\hline FN594545.1 & AACAACGGAA & CGATCGACTT & CCCCGGTATG & TGATAGATCT & ACGCCTGTAA & GGCGGGAATG \\
\hline \multirow[t]{2}{*}{ UFLADCA01 } & AACAACGGAA & CGATCGACTT & CCCCGGTATG & TGATAGATCT & ATGCCTATAA & GGCGGGAATG \\
\hline & 305 & 315 & 325 & 335 & 345 & 355 \\
\hline EU163268.1 & CCGTATGGGT & TGTGATTGAC & TTTTGCCGCC & AGAATTCCTC & ACCATGATGG & CTCGTAAGAT \\
\hline FN594545.1 & CCGTATGGGT & TGTGATTGAC & TTTTGCCGCC & AGAATTCCTC & ACCATGATGG & CTCGTAAGAT \\
\hline \multirow[t]{2}{*}{ UFLADCA01 } & CCGTATGGGT & TGTGATTGAC & TTTTGCCGCC & AGAATTCCTT & ACCATGATGG & CTCGTAAGAT \\
\hline & 365 & 375 & 385 & 395 & 405 & 415 \\
\hline EU163268.1 & GAAGGACACC & GACTCCGAGG & AGGAAATCCG & CGAGGCTTTC & AAGGTCTTCG & ACCGCGACAA \\
\hline FN594545.1 & GAAGGACACC & GACTCCGAGG & AGGAAATCCG & CGAGGCTTTC & AAGGTCTTCG & ACCGCGACAA \\
\hline \multirow[t]{2}{*}{ UF LADCA01 } & GAAGGACACC & GACTCCGAGG & AGGAAATCCG & CGAGGCTTTC & AAGGTCTTCG & ACCGCGACAA \\
\hline & 425 & 435 & 445 & & & \\
\hline EU163268.1 & CAATGGTTTC & ATCTCCGCCG & CGGAGTT & & & \\
\hline FN594545.1 & CAATGGTTTC & ATCTCCGCCG & CGGAGTT & & & \\
\hline UF LADCA01 & CAATGGTTTC & ATCTCCGACG & CGGAGTT & & & \\
\hline
\end{tabular}

Figure 4. Nucleotide sequence alignment of a portion from the calmodulin gene of A.costaricaensis (EU163268.1 and FN594545.1) and Aspergillus sp UFLA DCA 01. The gray markers indicate nucleotide substitutions. 


\section{ACKNOWLEDGEMENTS}

We thank Prof. Dr. Rodrigo Lopes Ferreira of the Biology Department and his team; to $\mathrm{CNPq}$ (National Counsel of Technological and Scientific Development) for financing the project Structure of the Cave Communities within the Brazilian Caatinga; to FAPEMIG (Foundation to Support of Research of the Minas Gerais State) to support the Laboratory of Electron Microscopy and Ultrastructural Analysis of the Federal University of Lavras, Brazil.

\section{REFERENCES}

1. Abarca, M.L.; Accensi, F.; CANO, J.; Cabañes, F.J. (2004). Taxonomy and significance of black aspergilli. Antonie van Leeuwenhoek. 86, 3349.

2. Al-Mussalam, A. Revision of the black Aspergillus species. (1980). University of Utrecht, Netherlands.

3. Altschul, S.F.; Gish, W.; Miller, W.; Myers, E.W.; Lipman, D.J. (1990). Basic local alignment search tool. J. Mol. Biol. 215, 403-410.

4. Azevedo, A.C.S.; Furlaneto, M.C.; Soza-Gomez, D.R.; Fungaro, M.H.P. (2000). Molecular characterization of Paecilomyces fumosoroseus (Deuteromycotina Hyphomycetes) isolates. Sci. Agric 57, 729-732.

5. Bennett, J.W.; Klich, M. Mycotoxins. (2003). Clinical Microbiol Review, $16,497-516$.

6. Filtenborg, O.; Frisvad, J.C. (1980). A sample screening method for toxigenic moulds in pure cultures. Lesbensmittel-Wissnschaft Technol. $13,128-130$.

7. Frisvad, J. C.; Samson, R. A. (2004). Polyphasic taxonomy of Penicillium subgenus Penicilium: a guide to identification of food and air-borne terverticillate Penicillia and their mycotoxins. Stud. Mycol. 49, $1-173$.

8. Geiser, D.M.; Klich, M.A.; Frisvad, J.C.; Peterson, S.W.; Varga, J.; Samson, R.A. (2007). The current status of species recognition and identification in Aspergillus. Stud. Mycol. 59, 1-10.

9. Glass, N.L.; Donaldson, G.C. (1995). Development of primer sets designed for use with the PCR to amplify conserved genes from filamentous Ascomycetes. Appl. Environ. Microbiol. 61, 1323-1330.

10. Hong, S.; Cho, H.; Shin, H.; Frisvad, J.C; Samson, R.A (2006). Novel Neosartorya species isolated from soil in Korea. Int. J. S. Evol. Microbiol. 56, 477-486.

11. Iamanaka, B.T.; Taniwaki, M.H.; Menezes, H.C.; Vicente, E.; Fungaro, M. H.P. (2005). Incidence of toxigenic fungi and ochratoxin A in dried fruits sold in Brazil. Food Add. Contam. 22, 1258-1263.

12. Klich, M.A. Identification of Common Aspergillus species. (2002). Netherlands: Centraalbureau voor Schimmelautures.

13. Klich, M.A.; Pitt, J.I. (1988). A laboratory guide to common Aspergillus species and their teleomorphs. North Ryde.

14. Leong, S.L.; Hocking, A.D.; Scott, E.S. (2007). Aspergillus producing ochratoxin A: isolation from vineyards soils and infection of Semillon bunches in Australia. J. Appl. Microbiol. 102, 124-133.

15. Magnoli, C.; Violant, M.; Ccombina, M.; Palacio, G.; Dalcero, A. (2003). Mycoflora and ochratoxin-producing strains of Aspergillus section Nigri in wine grapes in Argentina. Lett. Appl. Microbiol. 37, 179184.

16. Noonim, P.; Mahakarnchanakul, W.; Varga, J.; Frisvad, J.C.; Samson, R.A. (2008). Two novel species of Aspergillus section Nigri from Thai coffee beans. Int. J. S. Evol. Microbiol. 58, 1727-1734.

17. Oliveri, C.; Torta, L.; Catara, V. A. (2008). Polyphasic approach to the identification of ochratoxin A-producing black Aspergillus isolates from vineyards in Sicily. Int. J. Food Microbiol. 127, 147-154.

18. Perrone, G.; Varga, J.; Susca, A.; Frisvad, J.C.; Stea, G.; Kocsubé, S.; Tóth, B.; Kozakiewicz, Z.; Samson, R. A. (2008). Aspergillus uvarum sp. nov., an uniseriate black Aspergillus species isolated from grapes in Europe. Int J S Evol Microbiol. 58, 1032-1039.

19. Pitt, J. L.; Hocking, A. D. (1997). Fungi and food spoilage. Cambridge: Chapman \& Hall.

20. Pontecorvo, G.; Roper, J.A.; Hemmons, L. M.; Macdonald, K.D.; Bufton, A.W.J. (1953). The genetics of Aspergillus nidulans. Adv. Genet. 5, 141-148.

21. Rosa, C.A. da R.; Palacios, V.; Combinas, M.; Fraga, M.E.; Oliveira, R.; Magnoli, C.E.; Dalcero, A.M. (2002). Potential ochratoxin A from wines grapes in Argentina and Brazil. Food Add. Contam. 19, 408-414.

22. Samson, R.A.; Houbraken, J.A. M.P.; Kuijpers, A.F.A.; Frank, M.J.; Frisvad, J.C (2004). New ochratoxin A or sclerotium producing species in Aspergillus section Nigri. Stud. Mycol. 50, 45-61.

23. Samson, R.A.; Noonim, P.; Meijer, M.; Houbraken, J.; Frisvad, J.C.; Varga, J. (2007). Diagnostic tools to identify black Aspergilli. Stud. Mycol. 59, 129-145.

24. Sanger, F.; Nicklen, S.; Coulson, A.R. (1977). DNA sequencing with chain: terminating inhibitors. Proc Natl Acad Sci USA, 74, 5463-5467.

25. Serra, R.M.A. (2005). Micoflora das uvas portuguesas e seu potencial para a contaminação das uvas com micotoxinas, com destaque para a ocratoxina A. Lisboa, Portugal, 330p. (Doutorado em Engenharia Química e Biológica-Escola de Engenharia da Universidade do Minho, Lisboa).

26. Valero, A.; Oliván, A.; Marín, S.; Sanchis, V.; Ramos, A. J. (2007). Effect of intra and interspecific interaction on OTA production by A. 
section Nigri in grapes during dehydration. Food Microbiol. 24, 254-259.

27. Varga, J.; Kocsubé, S.; Tóth, B.; Frisvad, J.C.; Perrone, G.; Susca, A.; Meijer, M.; Samson, R.A. (2007). Aspergillus brasiliensis sp. nov., a biseriate black Aspergillus species with world-wide distribuition. Int. J. S. Evol. Microbiol. 57, 1925-1932.
28. Vries, R.P. de; Frisvad, J.C.; Vondervoort, P.J.I.; Burgers, K.; Kuijpers, A. F.A.; Samson, R.A.; Visser, J. (2005). Aspergillus vadensis, a new species of the group of black Aspergilli. Antonie van Leeuwenhoek. 87, 195-203. 